\title{
ANALISIS KEUNIKAN DAN “MISSING LINK” ANTARA HUKUM PIDANA INTERNASIONAL, ETIKA PROFESI, DAN POLITIK; TELAAH KRITIS PERPPU NOMOR 1 TAHUN 2016 TENTANG PERUBAHAN ATAS UU NOMOR 23 TAHUN 2002 TENTANG PERLINDUNGAN ANAK
}

\author{
Sobirin Malian \\ Universitas Proklamasi '45 Yogyakarta \\ Dosen Hukum Pidana \\ Email: $\underline{\text { sobirin2810@gmail.com }}$
}

\begin{abstract}
Abstrak
Kejahatan seksual yang meningkat fantastis baik secara kuantitatif maupun kualitatif di tahun 2016 ini, khususnya pada anak-anak, menghentak kita semua. Pemerintah pun lalu menetapkan negara dalam keadaan "darurat kejahatan seksual". Beriringan dengan itu formula hukum pun dicari agar kejahatan seksual dapat ditekan seminimal mungkin. Puncaknya Presiden mengeluarkan Peraturan Pemerintah Pengganti Undang-Undang (PERPPU) No.1 Tahun 2016. Persoalannya, PERPPU tersebut sejatinya mengandung "keanehan" dan "keunikan" di mana antara asas hukum satu dengan asas hukum lainnya saling bertentangan dan antara substansi hukum dan substansi etika profesi juga berlawanan, juga antara policy (perspektif politik) PERPPU yang dikeluarkan juga mengandung inkonsistensi atau "missing link" baik secara teori (das sollen) maupun dengan penerapannya (das sein).
\end{abstract}

Kata kunci: Kejahatan seksual, pidana, etika profesi dan politik

\section{ABSTRACT}

The sexual crimes, particularly happened to children, fantastically increase in 2016. The cases that increase both quantitatively and qualitatively surprise us. The government declares that the state is in the "emergency of sexual crimes." Along with it, the effort to seek the rule of this law is initiated to diminish the sexual crimes. Finally, the President issues the Government Regulation in Lieu of Act (PERPPU) No. 1 of 2016. The problem is this regulation has peculiarity and uniqueness. There is a contradictory among each principle also among law substance and profession ethics substance. There is an inconsistency or missing link among the policy (politic perspective) and the Government Regulation in Lieu of Act, both theoretically (das sollen) and the implementation (das sein).

Keywords: Sexual crimes, criminal, professional ethic, and politic

\section{A. LATAR BELAKANG}

Peristiwa perkosaan dan pembunuhan terhadap Yy (14 tahun) 2 April 2016 yang digilir oleh 14 remaja di Bengkulu pada awal Mei 2016 lalu menjadi semacam klimaks dari rentetan kasus kekerasan dan perkosaan, khususnya terhadap anak. 
Peristiwa itu lalu mengungkap banyak kasus lain di seluruh Indonesia yang selama ini terpendam dan kemudian makin mengagetkan karena kualitas dan kuantitasnya ternyata sangat tinggi.

Pusat Data dan Informasi (Pusdatin) Komisi Perlindungan Nasional Anak 2010-2014 mencatat ada 21.689.797 kasus pelanggaran hak anak yang tersebar di 34 provinsi dan di 179 kabupaten/kota (Pusdatin, 2016). 58\% dari pelanggaran hak anak tersebut merupakan kejahatan seksual. Sisanya 42\% adalah kasus kekerasan fisik, penelantaran, penculikan, eksploitasi ekonomi, perdagangan anak untuk tujuan eksploitasi seksual komersial, serta kasus-kasus perebutan anak.

Sementara data lain, dari Komisi Nasional Perempuan 2015, kekerasan seksual yang terjadi di ranah personal dari jumlah kasus sebesar 321.753, kekerasan seksual menempati peringkat kedua, yaitu dalam bentuk perkosaan sebanyak 72\% (2.399 kasus), dalam bentuk pencabulan sebanyak $18 \%$ (601 kasus), dan pelecehan seksual $5 \%$ (166 kasus). Pada ranah publik, dari data sebanyak 31\% (5.002 kasus), jenis kekerasan terhadap perempuan tertinggi adalah kekerasan seksual (61 \%). Pelaku kekerasan seksual adalah lintas usia, termasuk anak-anak jadi pelaku (Catatan Tahunan Komnas Perempuan, 2015).

Jika disimpulkan dari data resmi berbagai lembaga terkait perlindungan dan hak-hak anak itu maka masifnya kejahatan terhadap anak sangatlah ironis. Tak pelak lagi berbagai media (termasuk media sosial) dan masyarakat terus menyorot dan mengkritisi masifnya jenis kejahatan ini, yang akhirnya membuat pemerintah menyatakan "Indonesia darurat kejahatan seksual anak".

Sebagai antisipasi atas kedaruratan kejahatan seksual anak tersebut, pemerintah kemudian menerbitkan Peraturan Pemerintah Pengganti UndangUndang (PERPPU) Nomor 1 Tahun 2016 tentang Perubahan Atas UU Nomor 23 Tahun 2002 tentang Perlindungan Anak.

Penerbitan PERPPU Nomor 1 Tahun 2016 itu ternyata bukanlah tanpa masalah secara akademis, atas dasar itulah dalam tulisan ini paling tidak merumuskan tiga hal yang akan dijawab, yaitu:

1. Apakah PERPPU tersebut sudah tepat sebagai solusi hukum (karena "ihwal kegentingan yang memaksa" bersifat multitafsir)?

2. Bukankah pemberatan pidana (baik penjara maupun kebiri) tidak sejalan dengan komitmen Indonesia yang telah meratifikasi Convention Against Torture and Other Cruel, Inhuman or Degrading Treatment or Punishment 1984, dengan mengeluarkan UU No. 5 Tahun 1998?

3. Hukuman pengebirian yang eksekusinya harus dilakukan oleh Dokter (IDI), ternyata ditolak karena bertentangan dengan Kode Etik Profesi Kedokteran, bagaimana solusinya?

Dari tiga rumusan masalah tersebut, maka menurut penulis masalah ini sangat menarik karena terasa "aneh" dan "unik" jika dilihat dari kacamata akademis. Atau secara teoritis, dalam paradigma Gelilean yang menjadi cikal bakal paradigma scientism (atau dikenal juga dengan positivisme), bertolak dari aksiomatik bahwa alam semesta ini pada hakikatnya adalah himpunan fenomen yang berhubungan 
secara interaktif dalam satu jaringan kausalitas yang sekalipun dinamik, namun juga deterministik dan mekanistik. Berdasarkan fenomena ini, kejahatan seksual, terutama pada anak-anak, akan selalu dapat dijelaskan sebagai penyebab atau akibat dari fenomena yang lain. Hubungan sebab akibat seperti ini dikatakan berlangsung tanpa henti dan tanpa mengenal titik henti di tengah alam objektif yang inderawi. Dikatakan bahwa hubungan kausalitan antar-fenomena itu dikuasai oleh suatu imperatif alam yang berlaku universal, dan yang oleh sebab itu dapat saja berulang atau diulang, di manapun dan kapanpun, asal saja syarat atau kondisinya tak berbeda atau tak berubah (Wignjosoebroto, 2011: 10).

\section{B. METODE PENELITIAN}

Paper atau artikel ini termasuk studi pustaka. Intinya, pertama, mengumpulkan data primer seperti bahan hukum, peraturan perundang-undangan; lalu kedua, bahan sekunder, seperti berbagai tulisan (opini), berita, karya ilmiah, buku, jurnal, data-data dari lembaga terkait; dan ketiga, bahan tersier yaitu bahanbahan penunjang, seperti kamus, ensiklopedi dan sebagainya.

Analisis kajian ini adalah deskriptif normatif-teoritis. Penentuan deskriptif normatif-teoritis ini didasarkan pada dua alasan, yaitu: Pertama, mendekati masalah dari fakta-fakta (data-data) dari berbagai sumber yang ada, kemudian menganalisis aspek norma-norma hukum yang ada sekaligus mengkritisinya. Kedua, analisis tulisan ini bermaksud menjelaskan hubungan antara dua variabel, yaitu variabel penyimpangan atau penyalahgunaan kekuasaan (sifat ambigu penguasa) didalam mempersepsikan konstitusi terutama Pasal 22 (1) UUD 1945 tentang PERPPU dan itu tidak lepas dari variabel karena kelemahan hukum dasar tertulis ayat (1) tentang "ihwal kegentingan yang memaksa", yang multi tafsir.

Pendekatan teori yang digunakan dalam tulisan ini adalah hukum positif Indonesia. Diartikan sebagai hukum positif adalah: "kumpulan asas dan kaidah hukum tertulis dan tidak tertulis yang pada saat ini sedang berlaku dan mengikat secara umum atau khusus dan ditegakkan oleh atau melalui pemerintah atau pengadilan dalam negara Indonesia. Penekanan "pada saat ini sedang berlaku," karena secara keilmuan rechtwetenschap, pengertian hukum positif diperluas (Manan, 2014: 3-4). Bukan saja yang sedang berlaku sekarang dan akan berlaku (ius constituendum) (UU No.5 Tahun 1986 Tentang PTUN, Pasal 45), melainkan termasuk juga hukum yang pernah berlaku di masa lalu (ius constitutum) (UU No.5 Tahun 1986 Tentang PTUN, Pasal 45). Kalau merujuk pada ajaran-ajaran "legisme" atau "positivisme" Kelsen atau John Austin, bahwa hukum itu semata-mata kehendak dari penguasa (command of the sovereign) dalam bentuk peraturan perundang-undangan (Morris (ed), 1971: 336).

Unsur terpenting dari hukum positif, yaitu:

1. Hukum Positif "mengikat secara umum atau khusus."

Mengikat secara umum adalah aturan hukum yang berlaku umum yaitu peraturan perundang-undangan (UUD, UU, PERPPU, PP, Perda), hukum adat, yurisprudensi. Sementara yang mengikat secara khusus adalah hukum yang 
mengikat subyek tertentu saja atau obyek tertentu yaitu secara keilmuwan (dalam hukum administrasi negara) disebut beschikking.

2. Hukum positif "ditegakkan oleh atau melalui Pemerintah atau pengadilan."

Hukum positif ditegakkan atau dipertahankan oleh atau melalui pemerintah atau oleh pengadilan. Ciri ini menimbulkan paham bahwa hukum positif adalah aturan hukum yang mempunyai sifat memaksa dengan memberikan sanksi (hukuman). Ini sesuai dengan pendapat John Austin, yang mengartikan sanksi semata-mata sebagai suatu bentuk membebankan penderitaan/punishment (Sanusi, 1984: 113; ). Namun, banyak juga aturan hukum positif yang tidak mencantumkan suatu sanksi atau sifat memaksa tertentu atau suatu akibat hukum tertentu. Misalnya, kaidah-kaidah hukum hukum tata negara. Memperhatikan dua hal (sanksi mebebankan dan hanya sanksi administrasi), ilmu hukum membedakan antara hukum yang memuat aturan memaksa ( $d$ wingendrecht), dan juga yang semata-mata memuat aturan yang mengatur (regelendrecht).

Teori lain yang digunakan adalah teori tentang etika. Etika berasal dari bahasa Yunani ethos artinya kebiasaan, kandang, adat, akhlak, sikap, cara berpikir (K.Bertens, 1999; 45, O.P. Simorangkir, 2004;155-176 ). Dalam Kamus Besar Bahasa Indonesia (Poerwadarminta, 2010: 278), "etika" dijelaskan dengan tiga arti: 1) Ilmu tentang apa yang baik dan apa yang buruk dan tentang hak dan kewajiban moral (akhlak); 2) kumpulan asas atau nilai yang berkenaan dengan akhlak; 3) nilai mengenai benar dan salah yang dianut suatu golongan atau bermasyarakat."

Sementara setiap profesi memiliki kitab undang-undang etika atau Kode Etik. Mereka inilah yang senantiasa menegakkan etika apa yang boleh dan tidak boleh dilakukan dengan standar moral yang tinggi terhadap pelayanan profesinya.

Teori yang juga akan digunakan dalam menganalisis PERPPU ini adalah teori hirarki norma hukum yang digagas oleh Hans Kelsen (Kelsen, 1995: 14-31; Utsman, 2011: 20-26; Indrati Soeprapto, 1998: 2-3).

\section{PEMBAHASAN}

\section{PERPPU: Multitafsir "ihwal kegentingan yang memaksa"}

Secara konstitusional, PERPPU memang produk hukum yang sah (Sumali, 2003: 69-75). Pada Pasal 22 Ayat (1) UUD 1945 disebutkan, "Dalam hal ihwal kegentingan yang memaksa, Presiden berhak menetapkan peraturan pemerintah pengganti undang-undang." Penetapan PERPPU oleh Presiden juga tertuang dalam Pasal 1 ayat (4) UU No. 12 Tahun 2011 tentang Pembentukan Peraturan Perundangundangan, "Peraturan Pemerintah Pengganti Undang-Undang adalah Peraturan Perundang-undangan yang ditetapkan oleh Presiden dalam hal ihwal kegentingan yang memaksa." Selanjutnya, ayat (2) menetapkan bahwa, "Peraturan pemerintah itu harus mendapat persetujuan Dewan Perwakilan Rakyat dalam persidangan berikut." Konsekuensinya apabila ternyata tidak mendapat persetujuan oleh DPR, maka menurut ayat (3) Pasal 22 UUD 1945, PERPPU itu harus dicabut. 
Kajian yang akan disinggung di sini mengenai apa arti "dalam hal ihwal kegentingan yang memaksa?" Menurut penjelasan resmi UUD 1945, frase tersebut merupakan terjemahan dari noodverordeningsrecht. Menurut bahasa hukum Amerika, ini sama dengan konsep 'clear and present danger', situasi bahaya yang terang benderang dan memaksa. 'Nood' mengandung arti bahaya atau darurat. 'Ordenen' berarti mengatur, menyusun. Secara harfiah, 'noodverordeningsrecht' bisa diartikan peraturan hukum untuk mengatur keadaan bahaya/darurat (Mahendra, Republika, 8 September 2000; Rajagukguk, 2009: 76-77). Menurut penjelasan UUD 1945, PERPPU perlu diadakan agar keselamatan negara dapat dijamin pemerintah dalam keadaan genting. Namun, secara a contrario, pemerintah tidak boleh atau dilarang konstitusi untuk menerbitkan PERPPU manakala tidak ada hal ihwal kegentingan yang memaksa.

Oleh karenanya, logika penerbitan PERPPU bisa disusun apabila: pertama, ada situasi bahaya, kegentingan. Kedua, situasi bahaya ini dapat mengancam keselamatan negara jika pemerintah tidak secepatnya mengambil tindakan konkret. Ketiga, karena situasinya amat mendesak, dibutuhkan tindakan pemerintah secepatnya; sebab jika peraturan yang diperlukan untuk menangani situasi genting itu menunggu mekanisme DPR/DPD tentu memerlukan waktu lama.

Merujuk pada bahasa Jimly Asshidiqie, setidaknya terdapat tiga kondisi keadaan darurat yang dapat mengakibatkan suatu kegentingan memaksa, yaitu darurat perang; darurat sipil; dan darurat internal (innere not stand). Darurat yang sifatnya darurat internal dapat timbul berdasar pada penilaian subyektif Presiden, yang selanjutnya bisa menjadi alasan bagi Presiden untuk mengeluarkan PERPPU (Asshiddiqie, 2003: 273).

Kendati demikian, tidak adanya ketentuan perundang-undangan yang mengatur batasan-batasan kondisi kegentingan yang memaksa, sejatinya telah menjadikan PERPPU bak "bola liar" yang sewaktu-waktu dapat dimainkan oleh Presiden yang berkuasa untuk kepentingan kekuasaannya (Sihombing, 1996: 3-7). Jadi, PERPPU menjadi alat subyektif jabatan untuk menjustifikasi dirinya dalam memuluskan kepentingan kekuasaannya. Kita patut bersyukur sejauh ini tiap Presiden belum menjadikannya alat subyektif jabatan. Artinya, masih dalam batas kewenangannya untuk kepentingan negara. Pada masa lalu, misalnya, PERPPU No.3/2008 tentang Lembaga Penjaminan Simpanan (LPS) dikeluarkan 13 Oktober 2008, Presiden juga mengeluarkan PERPPU No.2/2008 tentang Perubahan Kedua UU.No.23/1999 tentang Bank Indonesia. Demikian pula di era Presiden SBY, mengeluarkan PERPPU No.4/2009 tentang Perubahan atas UU No. 30/2009 tentang Komisi Pemberantasan Korupsi. Lantas, bagaimana dengan PERPPU No.1 Tahun 2016 ini?

Kendati keluarnya PERPPU ini tidak perlu dicurigai berlebihan, namun dalam perspektif pemerintah, PERPPU ini adalah bentuk komitmen pemerintah terutama Presiden dalam menyelesaikan masalah kejahatan anak. Namun, PERPPU ini tetaplah produk hukum yang layak dikritisi karena multitafsir "ihwal kegentingan memaksa" yang rasa-rasanya belum mendapat argumen yang bulat terutama dari 
berbagai pakar hukum. Penting diperhatikan, bahwa harus dihindari dalam penerbitan PERPPU sebagai kebijakan hukum, yaitu adanya keterlibatan "emosi". Kita bisa berkaca dari policy yang sama yang pernah ada di Amerika yang dikenal dengan "Megan's Law". Megan berasal dari nama anak perempuan Megan Kanka yang tewas diperkosa oleh tetangganya di New Jersey pada 1994. Megan's Law (Human Rights Watch, 2008) karena dibuat dengan emosional yaitu untuk membalas dendam kepada tiap pelaku perkosaan, implementasinya tidak efektif bahkan kontraproduktif sehingga melahirkan ketidakadilan. "Megan's Law" adalah produk hukum parlemen yang motivasinya untuk menekan kejahatan seksual terhadap anak-anak dengan memfokuskan pada pemberatan ancaman pidana. Sayangnya, hukuman pidana klasik ini ternyata tidak efektif. Pada riset yang dilakukan oleh lembaga HAM negara bagian New Jersey, Amerika Serikat, terhadap pelaku kejahatan seksual selama 5 tahun sejak Megan Kanka (1994) diperkosa dan kemudian dibunuh, angka kejahatan seksual justru menunjukkan kecenderungan stagnan bahkan cenderung naik. Semula (1994) di New Jersey terjadi 32 kasus, tahun 1995-1996 menjadi 89 kasus, tahun 1997 menurun lagi menjadi 67 kasus, dan tahun 1998-1999 kecenderungan kejahatan seksual kembali naik menjadi 103 kasus (Irwanto, Kompas, 31 Mei 2016).

Jumlah ini relatif "wajar" dalam pandangan ahli hukum akibat berbagai faktor ekonomi dan ditambah lagi dengan budaya Amerika dan Eropa yang memang (permisif) menganut seks bebas (Abbink, 1994: 8-12; Wiyata, 2006: 229).

\section{Pemberatan Pemidanaan Inkonsisten dengan Konvensi PBB tahun 1984}

Harus dipahami di era sekarang, hukum dapat dipandang sebagai refleksi keberadaban suatu bangsa. Begitu juga jenis-jenis hukuman yang diancamkan akan mencerminkan tingkat kebudayaan yang telah dicapai oleh suatu masyarakat bangsa bersangkutan.

Perjalanan sejarah seringkali tidak linier, tetapi bersifat sirkuler. Artinya, hukuman dengan tujuan untuk membalas yang sejak lama telah ditinggalkan, sekarang malah muncul kembali sebagai respons maraknya kejahatan, dan kegagalan sistem peradilan pidana memberikan hukuman yang efektif terhadap kejahatan maupun penjahat (Manullang, 2006; Kompas, 17 Mei 2016). Teori retributif yang pernah dikembangkan Immanuel Kant telah bergeser ke arah teori resosialisasi dan bahkan rehabilitasi dengan dikedepankannya konsep keadilan restoratif.

Hukum maupun hukuman bukan semata-mata untuk pembalasan, atau perbaikan (resosialisasi). Hukum maupun hukuman juga dimaksudkan agar memulihkan keseimbangan yang terganggu akibat tindak pidana dengan mewajibkan kepada si pelanggar untuk mengganti kerugian terhadap korban dalam hal tindak pidana itu menimbulkan kerugian materiil.

Akan halnya terhadap tindak pidana yang tergolong luar biasa, di samping dijatuhkannya hukuman badan (penjara) dan denda, juga pembayaran uang pengganti dalam tindak pidana korupsi merupakan konsekuensi dianutnya ide 
double track system yang menggabungkan jenis hukuman (punishment) dan tindakan (treatment).

Pada konteks PERPPU di atas, sepanjang berkaitan dengan hukuman kastrasi telah menghidupkan kembali teori pidana klasik di mana hukuman dimaksudkan sebagai sarana pembalasan, yakni kejahatan dibalas dengan kejahatan pula. Implisit di dalam konsep itu mendukung nuansa apa yang disebut oleh Hobbes dengan homo homini lupus, yang konsekuensinya; manusia yang satu merupakan ancaman bagi manusia yang lain. Untuk menghilangkan ancaman itu, si pengancam harus dibinasakan.

Pada posisi inilah fungsi negara dipertaruhkan. Dalam tingkatan tertinggi, negara bertanggungjawab atas ide dihidupkannya kembali konsep klasik yang semata-mata ditujukan untuk membuat jera pelaku. Padahal, seperti dikatakan Cesare Beccaria, sesungguhnya penjeraan itu tidak pernah muncul dari hukuman yang berat, tetapi ditimbulkan dari pidana yang patut (Muladi dan Nawai, 1992: 16).

\section{Konvensi PBB: Pro Hukuman Manusiawi}

Perserikatan Bangsa-Bangsa sejak 1984 telah mengesahkan konvensi yang menentang penyiksaan, tindakan lain yang kejam, tidak manusiawi atau tindakan/hukuman yang merendahkan (Convention Against Torture and Other Cruel, Inhuman or Degrading Treatment or Punishment).

Berlakunya konvensi PBB itu kemudian diratifikasi oleh Indonesia melalui UU No.5/1998. Konsekuensinya, cara-cara yang tidak manusiawi dalam penegakan hukum, baik yang menyangkut proses penyidikan sampai peradilan, harus dihindarkan. Begitu juga ketentuan legislasi maupun hukuman yang merendahkan manusia, yang bersifat kejam, dan tidak manusiawi apalagi sampai melanggar HAM.

Meskipun hukuman kastrasi dipandang sebagai upaya terakhir di mana penerapannya harus seselektif mungkin, disebabkan karena pengulangan atau menimbulkan korban yang meluas, jenis hukuman itu tetaplah akan menimbulkan akibat yang tidak humanis. Pemberatan ancaman pidana yang secara alternatif diancamkan, seperti pidana mati, seumur hidup, atau 20 tahun jauh lebih manusiawi daripada hukuman badan (seperti pengebirian) yang pelaksanaannya masih diperdebatkan.

Hukuman kebiri dalam PERPPU memang hanya dijatuhkan terhadap pelaku yang telah dewasa. Akan tetapi, dengan diperberatnya hukuman, landasan filosofis maupun sosiologis hukuman kastrasi telah kehilangan relevansi. Konvensi di atas merupakan salah satu ketentuan universal yang dijiwai semangat self determination dan tetap mengindahkan prinsip the rule of law yang telah dipegang teguh Indonesia. Konsekuensinya, kita pun harus menyesuaikan peraturan perundangundangan maupun sistem penitensier agar Indonesia tidak dipandang sebagai negara yang melanggar hak asasi manusia.

Jadi, dengan dimasukkannya Pasal 81A dalam UU Perlindungan Anak yang mengakomodasi ayat di antaranya: (3) Pelaksanaan kebiri kimia disertai dengan rehabilitasi. Demikian pula dengan Pasal lain yang terkait dengan kebiri sejatinya telah bertentangan dengan semangat universal konvensi PBB yang dalam hirarki 
norma hukum dan harmonisasi hukum selayaknya kita ikuti. Inilah "keunikan" dan "keanehan" lain dari PERPPU No.1 Tahun 2016. Kebiri dalam hal ini menghambat libido, di mana testis tempat laki-laki memproduksi sperma dan hormon testosteron "dipasung". Hormon yang mematangkan sel-sel sperma sehingga siap membuahi sel telur dan juga memicu timbulnya libido tak akan lagi memproduski hormon testosteron, laki-laki itu tak akan lagi mempunyai gairah seks. Itulah dasar mengapa laki-laki dikebiri, supaya tidak terjadi pagar makan tanaman.

Teori perundang-undangan (gezetsgebungstheorie) pada dasarnya merupakan bagian dari ilmu pengetahuan perundang-undangan (gesetsgebungwissenschaft) yang berupaya mencari kejelasan makna atau pengertian-pengertian hukum dan peraturan perundang-undangan secara kognitif. Ilmu pengetahuan perundangundangan yang awalnya berkembang di Eropa Barat adalah ilmu yang bersifat interdisipliner di mana yang erat terkait adalah ilmu politik dan soosiologi. Ilmu perundang-undangan menurut Burkhart Krems, dalam karyanya Grundfragen der Gesetsgebungslehre, dapat dibedakan atas teori perundang-undangan dan ilmu perundang-undangan yang mengkaji aspek pembentukan undang-undang. Ilmu perundang-undangan dapat dirinci lagi ke dalam proses perundang-undangan (gesetsgebung-vehfahren), metode perundang-undangan (gesetsgebungs-methode), dan teknik perundang-undangan (gesets gebungs technik) (Indrati, 2007: 23).

Salah seorang ahli mazhab hukum murni yang pemikirannya tentang grundnorm dan hirarki norma hukum sangat berpengaruh terhadap hirarki norma hukum, yakni Hans Kelsen mengkategorikan hukum sebagai norma yang dinamik (nomodynamics). Menurut konsep ini hukum adalah sesuatu yang dibuat melalui suatu prosedur tertentu dan segala sesuatu yang dibuat menurut cara ini adalah hukum. Kaitannya dengan konstitusi, hukum dikonsepsikan sebagai sesuatu yang terjadi menurut cara yang ditentukan konstitusi bagi pembentukan hukum (Kelsen, 1995: 14-31).

Lebih jauh Kelsen mengungkapkan tentang karakter khas dan dinamis dari hukum, yaitu:

"hukum mengatur pembentukannya sendiri karena suatu norma hukum menentukan cara untuk membuat suatu norma hukum lainnya, dan juga sampai derajad tertentu menentukan isi norma lainnya tersebut ... Hubungan antara norma yang mengatur pembentukan norma lain dengan norma lainnya digambarkan sebagai hubungan antar "superordinasi" dan "subordinasi" ... Kesatuan norma-norma ini ditunjukkan oleh fakta bahwa pembentukan norma yang lebih rendah ditentukan oleh norma lain yang lebih tinggi, dan bahwa regressus ini diakhiri oleh suatu norma dasar, oleh karena menjadi dasar tertinggi dari validasi keseluruhan tata hukum, membentuk kesatuan tata hukum"

Selanjutnya Kelsen mengemukakan teorinya tentang tata urutan atau susunan hirarki dari tata hukum suatu negara, yaitu dengan mempostulasikan norma dasar, yakni konstitusi dalam arti material (Kelsen, 1995: 14-31) adalah urutan tertinggi di dalam hukum nasional. Sebagaimana ia tegaskan, bahwa: 
"the legal order...is therefore not a system of norms coordinated to each other, standing, so to speak, side by side on same level, but hierarchy of different levels of norms."

Masih menurut Kelsen, kendati konstitusi merupakan puncak tertinggi dalam hirarki norma hukum, namun tidak tertutup kemungkinan terjadinya konflik atau penyimpangan peraturan dan konstitusi. Mengenai hal ini, Kelsen mengemukakan prinsip lex posterior derogat priori dan prinsip desuetudo untuk mengatasi terjadinya konflik hukum tersebut. Prinsip atau azas lex posterior derogat lex priori menurut Kelsen adalah suatu undang-undang yang dibatalkan oleh undang-undang lainnya. Sedangkan prinsip desuetudo adalah akibat hukum yang bersifat negatif dari kebiasaan yang dapat mengabaikan undang-undang atau berakibat tidak efektifnya suatu undang-undang. Atau dengan kata lain, bisa saja suatu undang-undang kehilangan validitasnya karena dihapus oleh suatu kebiasaan (Hans Kelsen, 1995: 121 dan 158).

Gagasan Kelsen mengenai berjenjangnya lapisan norma hukum dalam suatu hirarki, di kemudian hari dikenal sebagai teori jenjang/hirarki norma hukum (stufentheorie) (Indrati Soeprapto, 1998: 25-26). Dalam bahasa Bagir Manan, ajaran tata urutan pertingkatan peraturan perundang-undangan (stufenbaudesrecht) mengandung makna: pertama, peraturan yang lebih rendah harus mempunyai sumber atau dasar pada peraturan yang lebih tinggi; Kedua, peraturan perundangundangan merupakan sebuah tertib hukum (legal order); dan ketiga, peraturan perundang-undangan untuk menjamin tata urutan itu dalam suatu sistem yang tertib (Manan, Republika, 21 Mei 2000).

Teori Kelsen ini kemudian dikembangkan lebih lanjut oleh salah satu muridnya, yakni Hans Nawiasky. Nawiasky menyatakan dalam bukunya yang berjudul Allgemeine Rechslehre, bahwa suatu norma hukum di negara manapun tidak saja selalu berlapis dan berjenjang, di mana norma yang di bawah berlaku dan mengacu pada norma di atasnya, sedangkan norma yang lebih tinggi berlaku dan bersumber pada norma yang lebih tinggi lagi, tetapi juga norma hukum itu berkelompok-kelompok. Kelompok norma hukum itu, ialah: (1) norma hukum fundamental negara (staatsfundamentalnorm);(2) aturan dasar atau aturan pokok negara (staatsgrundgesetz); (3) Undang-undang formal (formell gesetz;) (4) aturan pelaksana dan aturan otonom (verordnung und autonome satzung). Teori yang dikembangkan dari Stufentheorie Kelsen tersebut, selanjutnya oleh Nawiasky dinamai Die theorie vom stufenordnung der rechsnormen. Pada tahap lebih lanjut, teori hirarki norma (oleh Kelsen) dan dimodifikasi oleh Nawiasky, kedua teori ini seiring dengan kebutuhan dan dinamika hukum ketatanegaraan yang disintesakan menjadi theorie von stufennaufbau de rechtsordnung (Soejadi, 1999:101-104).

Jika kita kaji dengan kritis dan seksama theorie von stufennaufbau de rechtsordnung Kelsen-Nawiasky, maka kita akan melihat adanya refleksi teori tersebut dalam sistem norma hukum yang dianut di Indonesia. Ini sebagaimana dapat kita rujuk pada Ketetapan MPR No.III/MPR/2000 tentang Sumber Hukum dan Tata Urutan Perundang-undangan yang kemudian menjadi Undang-Undang Nomor 
10 tahun 2004 tentang Pembentukan Peraturan Perundang-undangan, selanjutnya kemudian direvisi kembali menjadi Undang-Undang Nomor 12 Tahun 2011 tentang Pembentukan Perundang-undangan.

Jadi, jika kita kembali pada konteks teori ini dan diharmonisasikan dengan Konvensi PBB tahun 1984 itu, maka jelas PERPPU ini inkonsisten keberadaannya. Juga apabila ditelisik substansi materi muatannya, maka PERPPU ini telah berlawanan dengan Konvensi PBB yang ingin mengurangi pidana fisik. Bahkan dalam perspektif keadilan kecenderungan konvensi PBB yang sudah berlaku di beberapa negara Eropa adalah konsep keadilan restoratif. Bahwa hukum bukan semata-mata untuk pembalasan. Walaupun permasalahan hukum dan keadilan telah lama menjadi perhatian yang menarik dan hingga kini masih aktual. Hukum dan keadilan tetap diperlukan sebagai nilai dari kebutuhan asasi bagi masyarakat beradab (Bakhri, 2016: 58).

\section{Hukum Versus Etika Profesi}

Pemberlakuan PERPPU No.1 Tahun 2016, di antara pasal di dalamnya memuat keharusan dokter sebagai pihak yang akan mengeksekusi. Akibat pasal itu, secara yuridis, mau tidak mau dokter harus melaksanakannya tanpa reserve, karena ini adalah hukum negara. Namun kenyataannya bunyi "hukum" tersebut ditolak oleh para dokter. Para dokter beralasan jika mereka mengeksekusi kebiri tersebut maka akan bertentangan dengan nilai dasar etika (Kode Etik Kedokteran Indonesia/Kodeki). Walaupun tiap negara berbeda-beda kode etik kedokterannya, namun khusus para dokter Indonesia paling tidak mengurai dalam empat alasan (asas) utama.

Asas manfaat, sebagai pelaksanaan dari ibadah dan menolong memberikan yang terbaik. Dalam kode etik kedokteran Indonesia dirumuskan dalam dua pasal, yaitu pasal kepentingan pasien menjadi ukuran utama dan dokter bekerja dengan ukuran yang tertinggi di samping pada sumpah kedokteran.

Berdasar asas manfaat tersebut, melakukan kebiri tentu tak ada manfaatnya sama sekali. Dengan demikian, apabila kebiri dilakukan oleh seorang dokter, ia akan melanggar etik. Dari aspek medis teknis pelaksanaan tidaklah sederhana; perlu melibatkan dokter ahli bedah, ahli anestesi, ahli kedokteran jiwa. Bahwa dalam sejarah sudah ada pengebirian pada manusia, tidak berarti itu benar jika dilakukan.

Asas jangan mencederai atau jangan merugikan. Inilah prinsip sebagai penegasan dari asas manfaat. Asas ini berlaku dari segala aspek kehidupan, jangan mencederai dari segi spiritual (hak beribadah), jangan mencederai dari aspek psikologi, yaitu kewajiban menyimpan rahasia kedokteran, aspek finansial jangan sampai pasien mengeluarkan biaya yang bukan diperlukan. Berdasarkan asas ini, kebiri akan mencederai pasien dan sangat merugikan karena kehilangan hak berketurunan. Hak berketurunan sejatinya ciptaan Tuhan (sunnatullah), jika manusia menghalangi sunnatullah itu dengan paksa, maka sama saja "menentang" kehendak Tuhan, hal yang sangat dihindari oleh para dokter.

Asas otonomi, mensyaratkan segala pikiran pertimbangan dan keputusan dokter yang akan dikerjakan wajib diketahui, disadari, dan disetujui oleh pasien. 
Bahkan, untuk tindakan yang berpotensi merusak jaringan, diperlukan surat persetujuan tertulis. Untuk itu, terhukum kebiri berhak meminta dokter mentaati UU Praktik Kedokteran (2013), jadi ia berhak menolak. Pertanyaannya, apakah pemerintah dapat memaksa dokter dan perawat melanggar etika dan sekaligus melanggar UU?

Secara teori Kode Etik sangat mem-pribadi sifatnya sebagai (akhlaqul karimah) yang melekat kuat dalam keprofesionalitasan, sementara hukum adalah kehendak negara (command of sovereignty). Keduanya memang dapat seiring sejalan manakala ada muara pertemuan, yaitu sama-sama untuk kepentingan kemanusiaan. Akan tetapi, akan saling bertentangan bilamana yang satu sudah memasuki wilayah "politik" seperti halnya PERPPU No.1 Tahun 2016 ini. Politik lebih sering melihatnya sebagai "alat" kuasa tanpa mempertimbangkan aspek humanisme. Atas dasar itu, sebaiknya ke depan produk hukum (pemerintah) harus sinergis dengan kode etik profesi apa pun dengan titik temunya demi kemanusiaan dan keadilan.

\section{PENUTUP}

\section{Kesimpulan}

Kejahatan dan kekerasan seksual khususnya pada anak-anak yang pada tahun 2016 ini cenderung menunjukkan peningkatan baik kualitas maupun kuantitasnya memang mencemaskan. Seperti dicatat oleh berbagai lembaga yang membawahi anak-anak yaitu Komnas Anak dan Komnas Perempuan, atau berbagai media massa.

Masyarakat dan pemerintah pun akhirnya sepakat bahwa jenis kejahatan ini telah masuk dalam kategori kejahatan "extra ordinary crime" atau darurat kejahatan. Tak pelak pemerintah pun lalu bereaksi dengan menerbitkan PERPPU Nomor 1 Tahun 2016 tentang Perubahan Atas UU Nomor 23 Tahun 2002 tentang Perlindungan Anak.

Sayangnya, PERPPU ini bukanlah tanpa masalah baik secara teori maupun implementasi hukum, terutama hukum internasional. Paling tidak ada tiga hal yang mengandung "keunikan" atau inkonsistensi di dalamnya. Pertama, PERPPU ini tetap menjadi polemik karena menurut Pasal 22 (1) UUD 1945, "hal ihwal kegentingan yang memaksa" adalah konsep debatabel. "Hal ihwal kegentingan yang memaksa" dalam konteks kejahatan yang diurai di atas rasa-rasanya belum layak menjadi dasar untuk segera dikeluarkannya PERPPU. Artinya, masih ada cara-cara atau policy lain yang dapat ditempuh guna mengatasi problem kejahatan dan kekerasan seksual terhadap anak ini.

Kedua, materi muatan dalam PERPPU dengan menambahkan pemberatan hukuman "kebiri" inkonsisten dengan konvensi PBB tahun 1984, padahal Indonesia adalah salah satu negara yang meratifikasi konvensi tersebut. Artinya, seharusnya jika konsisten dengan konvensi itu Indonesia harus mencari hukuman yang lebih bijak dan manusiawi. Secara teori pemberatan pidana apalagi yang bersifat "menyiksa" fisik seperti kebiri, di banyak negara sudah ditinggalkan. Terkesan 
pemberatan pidana lebih mirip hukuman balas dendam, di mana di dalamnya terkandung emosi.

Ketiga, hukuman dengan mengebiri pelaku, di mana "eksekusinya" harus dilakukan oleh dokter ternyata ditolak oleh IDI (Ikatan Dokter Indonesia). IDI berargumen, antara hukum positif (PERPPU) dengan Kode Etik Profesi Kedokteran, ternyata substansinya berlawanan. Ada asas-asas yang jika eksekusi itu tetap dilakukan oleh para dokter akan terlanggar. Mereka memilih menolak atas dasar Ketuhanan dan kemanusiaan.

\section{Saran}

Pertama, ada baiknya pemerintah dalam hal ini Presiden mempertimbangkan lebih matang lagi jika ingin mengeluarkan PERPPU. Kalimat "hal ihwal kegentingan yang memaksa" seperti termuat dalam pasal 22 UUD 1945, seharusnya dirumuskan secara lebih jelas dengan frase-frase hukum yang terukur. Dengan begitu perdebatan tentang "hal ihwal kegentingan yang memaksa" yang sejatinya subyektifitas Presiden dapat diakhiri.

Kedua, konvensi PBB sebagai policy universal, apa pun itu, jika memang sudah kita ratifikasi, harus konsisten ditaati. Harap dicatat bahwa sikap inkonsistensi kita terhadap hukum produk PBB akan membuat dunia internasional menyorot kita sebagai negara yang tidak jelas standar hukumnya. Pada banyak negara ketaatan hukum, kedisiplinan menjadi ukuran sejauh mana sebuah negara disebut maju. Hukum yang tegas, konsisten menggambarkan sebuah peradaban negara/bangsa disebut maju.

Ketiga, sebaiknya sebelum sebuah produk hukum diterbitkan, apalagi terkait dengan profesi tertentu, dapat didialogkan. Dibuat semacam matrik plus-minus jika profesi itu harus dilibatkan, sehingga tidak terjadi hukum terkesan vis a vis dengan kode etik profesi. Dialog akan menjernihkan persoalan, dan lebih dari itu substansi dan ke-sinergian akan lebih mudah dipertemukan.

\section{DAFTAR PUSTAKA}

\section{A. BUKU DAN JURNAL}

Abbink, A.J. (1994). Culture of Violence: A Comparative Study of Cultural Forms of Violence Behaviour. Nijmegen.

Asshidiqie, Jimly (2004). Konstitusi dan Konstitusionalisme, Jakarta: Mahkamah Konstitusi dan Pusat Studi Hukum Tata Negara FH UI.

Bakhri, Syaiful (2016). Pidana Denda: Dinamikanya dalam Hukum Pidana dan Praktek Peadilan. Yogyakarta: Kreasi Total Media Yogyakarta dan UMJ Jakarta.

Bentham,Jeremy (2010). Teori Perundang-undangan: Prinsip-prinsip Legislasi, Hukum Perdata dan Hukum Pidana, Bandung:Nuansa dan Nusamedia.

Bertens, K. (1999). Etika. Jakarta: Gramedia Pustaka Utama.

Hamidi, Jazim \& Mutik, Kemilau (2011). Legislative Drafting. Yogyakarta: Total Media. 
Indrati Soeprapto, Maria Farida (1998). Ilmu Perundang-Undangan: Dasar-dasar dan Pembentukannya. Yogyakarta: Kanisius.

Indrati Soeprapto, Maria Farida (2007). Ilmu Perundang-Undangan: Jenis, Fungsi, dan Materi Muatan. Yogyakarta: Kanisius.

Kelsen, Hans (1995). Teori Hukum Murni: Dasar-dasar Ilmu Hukum Normatif Sebagai Ilmu Hukum Empirik-Deskriptif. Jakarta: Rimdi Press.

Manan, Bagir (2014). Hukum Positif Indonesia (Suatu Kajian Teoritik). Yogyakarta: FH UII Press.

Manullang, E. Fernando M. (2006). Menggapa Hukum Berkeadilan: Tinjauan Hukum Kodrat dan Antinomi Nilai. Jakarta: Penerbit Kompas.

McCourberly, Hilaire \& D. White, Nigel (1999). Jurisprudence. Blackstone Press Limited.

Morris, Clarence (ed) (1971). The Great Legal Philosophers. Philadelphia: University of Pennsyvania Press.

Muladi dan Barda Nawawi (1992), Teori-teori dan Kebijakan Pidana, Bandung: Alumni.

Pusat Data dan Informasi Komnas Perlindungan Anak, Jakarta, April 2016.

Rajagukguk, Erman (2009). Yustisia "PERPPU". Jakarta: LSHU \& E.

Sanusi, Ahmad (1984). Pengantar Ilmu Hukum dan Pengantar Tata Hukum Indonesia. Bandung: Transito.

Sihombing, Herman (1996). Hukum Tata Negara Darurat. Jakarta: Djambatan.

Simorangkir, O.P. (2004). Etika: Bisnis, Jabatan, dan Perbankan. Jakarta: Rineka Cipta.

Soejadi (1999). Pancasila Sebagai Sumber Tertib Hukum Indonesia. Yogyakarta: Lukman Offset.

Sumali (2003). Reduksi Kekuasaan Eksekutif di Bidang Peraturan Pengganti UndangUndang (PERPU). Malang: UMM Press.

Tateki Yoga Tursilarini dan Trilaksmi Udiati (2016), Inses Di Ranah Domestik, Yogyakarta: Kreasi Total Media.

Utsman, Sabian (2011). Menuju Penegakan Hukum Progresif. Yogyakarta: Pustaka Pelajar.

W.J.S., Poerwadarminta (2010). Kamus Umum Bahasa Indonesia. Jakarta: Balai Pustaka.

Wignjosoebroto, Soetandyo (2011). Memperbincangkan 'Hukum' Dari Perspektif Filsafat: Paradigma Hukum dan Pergeserannya dalam Sejarah. Makalah dalam Semiloka dengan Tajuk "Forum Penyegaran Filsafat Hukum Indonesia di FH Universitas Katholik Parahyangan bekerjasama dengan Epistema Institute-HuMa, tanggal 8-9 Maret 2011 di Bandung.

Wiyata, A. Latief (2006). Carok, Konflik dan Harga Diri Orang Madura. Yogyakarta: LKiS.

\section{B. MEDIA CETAK}

Manan, Bagir (2000). Arogansi MPR. Republika, 21 Mei 2000. 
Djafar, Wahyudi (2009). "Bola Liar PERPPU”. Kompas, 12 Oktober 2009.

Mahendra, Yusril Ihza. Problematika Sekitar Perppu. Republika, 8 September 2000.

Irwanto (2016). Konsekuensi Perppu No 1/2016. Kompas 31 Mei 2016.

\section{Peraturan Perundang-undangan dan Dokumen Lain}

Catatan Tahunan Komnas Perempuan, Jakarta Tahun 2015.

PERPPU 3/2008 tentang Lembaga Penjaminan Simpanan (LPS) dikeluarkan 13 Oktober 2008.

PERPPU 4/2009 tentang Perubahan atas UU 30/2009 tentang Komisi Pemberantasan Korupsi.

PERPPU No.2 Tahun 2008 tentang Perubahan Kedua UU.No.23/1999 tentang Bank Indonesia.

UU No.5 Tahun 1986 Tentang PTUN. 